\title{
A Revised Linkage Map of Common Bean
}

\author{
Mark J. Bassett ${ }^{1}$ \\ Vegetable Crops Department, IFAS, University of Florida, Gainesville, FL 32611
}

It has been nearly 30 years since Lamprecht (1961a) published the linkage map of common bean (Phaseolus vulgaris L.). Since that time, numerous reports of additional linkages between marker genes have appeared (Awuma and Bassett, 1988; Gepts, 1988; Kyle et al., 1986; Lamprecht, 1961b; Nagata and Bassett, 1984; Park and Tu, 1986; Prakken, 1972b; Stavely, 1984; Temple and Morales, 1986; Weeden and Liang, 1985). Also, various authors (Bassett, 1988; Bassett and Awuma, 1988; Leakey, 1988; Prakken, 1970, 1972b, 1974) have challenged the interpretation and validity of some of the published data of Lamprecht. The current linkage map (Gepts, 1988) has 13 linkage groups with 46 marker genes. The current paper provides a revised linkage map of $P$. vulgaris based on a critical review of the above reports, includes new linkage data, and results in many revisions and deletions of old linkages. For definitions and descriptions of genes not given here, refer to the newly revised gene list for common bean (Bassett, 1989).

Linkage group I. Lamprecht (1961a) gave linkage group I as: Can-20-Ins-28Cor $-15-R-8-C-20-U c$. According to Prakken (1970, p. 3), Lamprecht's genes $C a n$ and $I n s$ are synonyms for $D$, the hilum ring factor. Therefore, a revised estimate for the linkage map distance between $D$ and the corona gene (Cor) must be calculated by combining Lamprecht's linkage data (1961a) for Can with Cor $(34.7 \pm 2.80)$ and Ins with Cor $(27.6 \pm 2.59)$. Using the maximum likelihood method (Allard, 1956) this estimate is $31.3 \pm 1.91 \mathrm{cM}$ with a homogeneity $x^{2}=3.769, P=0.10$ to 0.05 (Table 1).

The red seed coat gene $(R)$ and the gene $(C)$ for "eversegregating" seed coat color (heterozygotes are mottled in dark pattern/ light pattern) are closely linked in a "complex $C$ locus", according to Prakken (1970, p. 4). This view was based not only on his own data, but also on the published data of Feenstra and Nakayama (Prakken, 1970, p. 5). However, Prakken avoided comment on the extensive published data (four repulsion phase linkage tests) reported by Lamprecht $(1940,1947,1961$ a) that resulted in an estimate of eight map units between $\mathrm{C}$ and $R$.

Received for Duplication 30 Apr. 1990. Fla. Agr. Expt. Sta. Journal Series no. R-00629. The cost of publishing this paper was defrayed in part by the payment of page charges. Under postal regulations, this paper therefore must be hereby marked advertisement solely to indicate this fact. 'Professor.
A definitive resolution of this disagreement cannot be achieved without investigation of the $C-R$ region by molecular genetic techniques. In the interim, I favor the view of Prakken and question the large linkage value of Lamprecht because no one has been able to confirm or duplicate his results. Therefore, $R$ is tentatively assigned to the "complex $C$ locus" with a footnote indicating the uncertainty about the linkage value (Table 1). Brackets are used to indicate the very tight linkage within the "complex $C$ locus" (Table 1).

Prakken routinely used the combination gene symbol $C M$ to indicate what he called the "complex $C$ locus". In the series $C M$, $C m, c M, c m$, the dominant allele $M$ is a synonym for the marbled seed coat allele $\left(R^{m a}\right)$ at the $R$ locus, but the recessive allele $m$ is a schematic pseudoallele that conceals one's ignorance about which of many $R$ alleles is present in the material being described: patterned red $R$ alleles other than $R^{m a}$, the unpatterned red $R$ allele, or the colorless $r$ allele. The true status of $R$ is often not known due to the epistatic effects of $c$ and the colormodifying genes $G, B$, and $V$.

Prakken (1972b, 1974) studied the fine structure of the "complex $C$ locus" and obtained recombinant progeny, demonstrating (in part) that what were previously regarded as pleiotropic effects of certain alleles at the $R$ locus are, in fact, effects controlled by recombinable genes. Previously, Lamprecht (1947) had shown that at least seven alleles (or tightly linked loci) existed at the $R$ locus, which controlled the various genetic red seed coat patterns, such as marbling, striping, sprinkled, circumdatus-mottling, and rhomboid-mottling. The experiments of Prakken (1972b, 1974) with $C^{s t}$ and $C^{m}\left(R^{s t}\right.$ and $R^{m a}$ in the symbols of Lamprecht) led him to hypothesize the existence of other genes at the "complex $C$ locus" as a result of apparent crossing over within this locus. The multiple genes within the "complex $C$ locus" of Prakken include: an $M$ locus controlling mottled (or marbled) seed coat color that can be homozygous (whereas the $C / c$ mottle only occurs in the heterozygote); $\operatorname{Pr}$ for preventing the "flowing out" of redness; Acc for accompanying colors, i.e., the formerly "pleiotropic" effects of $R^{s t}$ on the color of pods, the top edge of the standard, and the hypocotyl; $C$ for producing dark pattern color; $R$ for unpatterned red; and $S t$ for restricting the red to stripes.

A critical examination of the data reveals that Prakken has only shown that a crossover occurred between the $R$ locus and the gene (see below) for $\mathrm{Pr}$ and Acc. There is no crossover evidence that justifies hypothesizing different genes for $M$ and $S t$ that are separate from $R$. I am not aware of any report that demonstrates that the five seed coat patterns of Lamprecht (1947) can occur in any color other than dominant red $(R)$, taking into account the modifying effects of $G, B$, and $V$. Prakken (1974, p. 3) implied that these patterns were observed in colors other than dominant red (discounting $G, B$, and $V$ effects), but provided neither data of his own nor citations of work by others. Similarly, there is no crossover evidence to justify separate genes for $P r$ and Acc. Hence, the gene symbols for $M$ and $S t$ are deleted from the "complex $C$ locus" (enclosed in brackets) and the symbols $\mathrm{Pr}$ and Acc are enclosed with parentheses to indicate the pleiotropic expression of this locus (Table 1). The true orientation of the four genes at the' "complex $C$ locus" is unknown.

According to Prakken (1970, p. 5), the gene $U c$ of Lamprecht (1961a), controlling color in the upper edge of the banner petal and the hypocotyl, is not a separate locus. Instead, the Terminalverstärkung der Blütenfarbe character of Lamprecht is another effect of the "complex $C$ locus", i.e., darkening of the banner tip is only expressed in the presence of $R^{s t}$ or $R^{m a}$ due to the effect of the gene Acc. The existence of $U c$ is doubtful, and it should be deleted from the map (Table 1).

Lamprecht (1961b) reported a linkage of $39 \mathrm{cM}$ between the aequicoloratus gene (Aeq) and the tricotyledonae gene (tri). Prakken (1970) regarded the Aeq gene to be an equivalent of $R^{s t}$, i.e., he attributed the darkening of the tip of the standard flower petal to a gene within the multiple genes at $C$. Thus, if the linkage is valid, tri must be linked to $C$ in linkage group I. There is no stock with tri extant in Lamprecht's seed collection, and there are insufficient data to orient tri in the map (Table 1). Leakey (1988) has incorrectly described the function of Aeq as deepening the color of the entire banner petal, whereas Lamprecht (1936, 1948a) clearly indicated that Aeq only darkens the tip of the banner petal.

Linkage group II. I support Leakey's (1988) suggestion that the genes $E a, E b, l a$, and $I b$, controlling the shape of pod cross sections, "should not reach marker status," because this is a quantitatively inherited trait. Similarly, Leakey (1988) states that the gene $(F a)$ for pod membrane (parchment) and the supplementary genes $(F b, F c, F d)$ for this trait are not "convenient or reliable for use as marker characters." The pod curvature gene $(D a)$ is probably a more reliable marker gene. 
The two linkages of linkage group II are retained in the map (Table 1), pending further investigation.

Linkage group III. Lamprecht's (1961a) linkage groups III and IV are as follows, respectively: $B-25-S t ; R k-38-B r$. According to Prakken (1972a), Smith's gene $\mathrm{Br}$ is a synonym for $B$, the locus for greenishbrown seed-coat color. Hence, linkage groups III and IV of Lamprecht should be combined and called group III (Table 1). Data are lacking to orient the red kidney seed-coat color gene $(R k)$ and the stringless pod gene $(S t)$ in relation to $B$. There is also good evidence for strong linkage between $B$ and Ane, the nebulosus seed coat mottling character, but Ane cannot be placed in the genetic map because the map distance was not calculated (Lamprecht, 1964; Prakken, 1977). Just as Prakken (1970) popularized the term "complex $C$ locus", it is useful now to coin the phrase "complex $B$ locus" for a very tightly linked group of genes associated with that locus. The work of Temple and Morales (1986) and Park and Tu (1986) has demonstrated that the effect of the $B$ locus is very tightly linked with (or pleiotropic for) the effect of the I locus for hypersensitive resistance to bean common mosaic virus (BCMV), i.e., no recombinant between $B$ and I were reported by these authors. However, the linkage between $B$ and $I$ has been broken either by recombination or mutation because recombinant plants with $b I$ have been found in a landrace, 'Pompadour', in the Dominican Republic (J. Beaver, personal communication). Hence, resistance to BCMV is not a pleiotropic effect of $B$. Similarly, it has been reported (Kyle and Provvidenti, 1987; Kyle et al., 1986) that three other virus resistances [cowpea aphid-borne mosaic virus $(\mathrm{Cam})$, blackeye cowpea mosaic virus $(\mathrm{Bcm})$, and watermelon mosaic virus-2 (Wmv)] have an uncertain genetic basis. They are either very tightly linked to $I$, or $I$ is pleiotropic for broad spectrum resistance to several virus diseases. The maximum genetic map distance across these four factors was found to be $<0.3 \mathrm{cM}$, i.e., if one recombinant had been found, the map distance would be 0.3 cM. Although no recombinant have been obtained among these genes, it is best to represent them as multiple loci within the "complex $B$ locus" until molecular genetic analysis can decisively answer the question. Parentheses within brackets are used to set the four virus loci apart from $B$ (Table 1). The true orientation of the genes within the "complex $B$ locus" is unknown.

Linkage groups $I V$ and $V$. Lamprecht (1961a) gave linkage group $\mathrm{V}$ as: fin-31No. The only stock (M0057) in the original seed collection of Lamprecht carrying the gene for nopal red flower color $(\mathrm{No})$ has been lost. According to my personal experience, this gene is rare, and it was derived from $P$. coccineus L. (Lamprecht, 1948b). Linkage group $\mathrm{V}$ is renumbered as IV, and Lamprecht's (1961a) linkage group VI is renumbered as $\mathrm{V}$ without any change (Table 1).

Linkage group VI. Lamprecht's (1961a) linkage group VII has been renumbered as
VI (Table 1). The top line of linkage group VI gives the original map of Lamprecht (1961a) except that the white seed and flower locus $(P)$, which was $18 \mathrm{cM}$ to the right of the minor intervallis gene (miv), has been deleted (Table 1). Bassett and Awuma (1988) demonstrated that the $P$ locus is not in the region of $s l$ and $r n d$. Linkage data comprising the bottom line of linkage group VI were obtained by Nagata and Bassett (1984). From the appearance of parallel maps for linkage group VI one might surmise that no effort has been made to integrate them, but such is not the case. For example, we grew Lamprecht's lines M0204, M0207, M0208, M0209, and V0863 in Gainesville, Fla., in Jan.-Mar. 1982. The lines carry a reclining foliage gene (Sur) according to the genetic notes of Stig Blixt. None of these lines expressed the expected reclining foliage (petioles slant downward from the place of attachment to the stem); hence, no linkage studies could be performed with them. Perhaps Sur is not expressed at the latitude of Gainesville $\left(30^{\circ} \mathrm{N}\right)$. Among the lines still extant in Lamprecht's collection, only one, V0741, is listed as carrying the caruncula wart gene (Cav), and this line does express the trait. There are no lines listed with miv and none expressed the strong reduction in the interval between the funcicles (resulting in flattened seed ends) controlled by this gene. Thus, it is likely that the gene is no longer extant in the collection.

Linkage group VII. Linkage group VIII (Lamprecht, 1961a) has been renumbered as group VII (Table 1). Lamprecht (1961a) gave linkage group VIII as: $V-35-U n c-13-$
Ia. The dominant allele at the $V$ locus is necessary to produce bishops violet (wild type) in flowers and the blue to black range of colors in the seed coat. A new linkage between $V$ and the reclining foliage gene $(r f)$ has been added to linkage group VII (Table 2). A Florida breeding line (5-593) carries the dominant allele at both marker loci. A small $\mathrm{F}_{2}$ planted in 1988 was not intended to be used for linkage study, but the double mutant class appeared to be too large to be a chance deviation. One double mutant plant was selected and $\mathrm{F}_{3}$ progeny were backcrossed with 5-593 to generate a much larger $\mathrm{F}_{2}$ in 1989 (Table 2). The linkage $x^{2}$ was highly significant for both years, and combined data gave a linkage estimate of $10 \mathrm{cM}$ (homogeneity $x^{2}=2.29$ with $P=0.13$ ).

Prakken (1970, p. 5) attributed the effects of Unc (Lamprecht, 1948a), which is similar to $U c$, to the "complex $C$ locus." Prakken (1937, p. 17) also reported that there is no linkage between $V$ and the "complex $C$ locus". To date, no one has confirmed the marker status of Lamprecht's gene Ia, which is involved with "flat" pods, i.e., elliptical pod cross section. In fact, Leakey (1988, p. 306), in his chapter reviewing the marker genes of common bean, has suggested that the complementary gene pair $I a I b$ not be accorded marker status. Therefore, I propose to drop Unc and Ia from linkage group VII, leaving only the newly reported linkage (Table 2).

Linkage group VIII. According to Prakken (1972a), the ground factor gene $(t)$ for partly colored seeds is linked to the circumlineatus gene $(\mathrm{cl})$ by $36 \mathrm{cM}$ (Table 1$)$. In partly col-

Table 1. Revised genetic linkage groups ${ }^{z}$ of common bean.

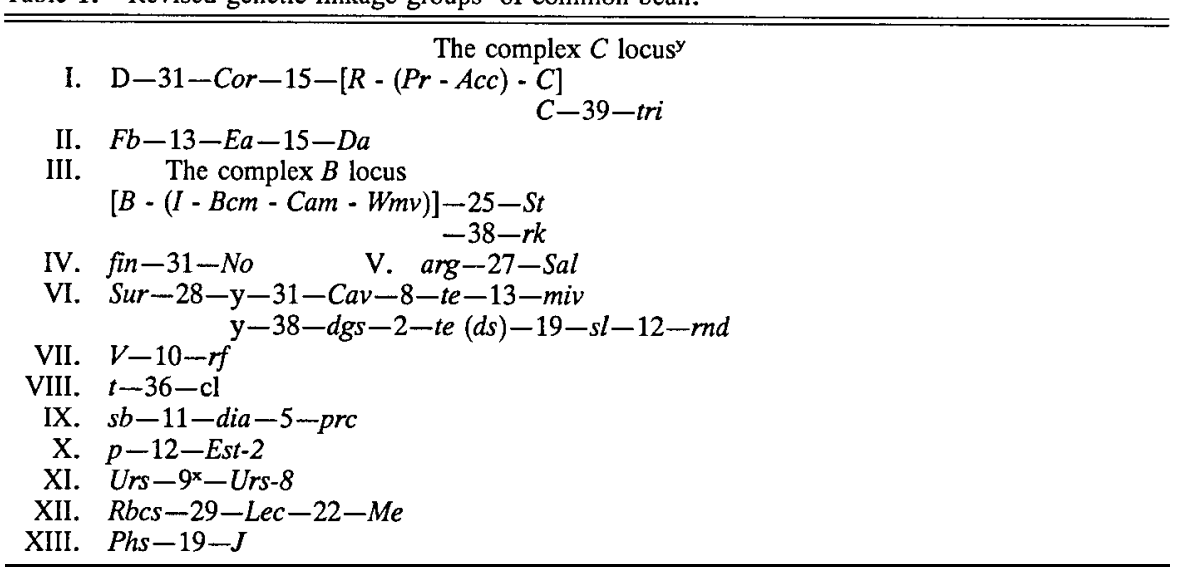

${ }^{2}$ Linear arrangement of marker gene symbols interspersed with the map distances in cM.

'The $R$ locus was reported to be $8 \mathrm{cM}$ from $C$ by Lamprecht $(1940,1947,1961 \mathrm{a})$.

Urs-2 through Urs-7 are located in this region.

Table 2. Estimation of the recombination percentage between the $r f$ and $v$ loci from two coupling phase linkage tests: the $\mathrm{F}_{2}$ from 5-593 $R f V$ 8-552 rf $v^{\text {lac }}$ in 1988 and the $\mathrm{F}_{2}$ from 8-552-1 ${ }^{2} \mathrm{~F}_{3} r f$ $\mathrm{v}^{\text {he }} \times 5-593$ in 1989 .

\begin{tabular}{|c|c|c|c|c|c|c|}
\hline \multirow[b]{2}{*}{ Year } & \multicolumn{4}{|c|}{ Phenotypic classes } & \multirow{2}{*}{$\begin{array}{c}\text { Linkage } \\
\chi^{2}\end{array}$} & \multirow{2}{*}{$\begin{array}{l}\text { Recombination } \\
\text { value }^{y}(\%)\end{array}$} \\
\hline & Normal & $R f+v^{\text {lac }}$ & $r f+V$ & $r f+\nu^{\text {lae }}$ & & \\
\hline 1988 & 81 & 5 & 10 & 15 & 32.50 & $15.93 \pm 3.84$ \\
\hline 1989 & 1007 & 62 & 63 & 257 & 699.73 & $9.76+0.84$ \\
\hline
\end{tabular}

${ }^{2}$ A selection derived from the previous cross planted as plot 8-552.

${ }^{y}$ Cornbined estimate for both years is $10.17 \pm 0.83$ (homogeneity $x^{2}=2.29$ ). 
ored seeds, $\mathrm{cl}$ produces a precipitation-like border line around the colored zone(s), including the smallest dots.

Linkage group IX. This is a new linkage group discovered among induced marker mutations (Awuma and Bassett, 1988; Nagata and Bassett, 1984), which includes the spindly branch gene $(s b)$, diamond leaf (dia), and progressive chlorosis ( $p r c$ ).

Linkage group $X$. This linkage was discovered by Weeden and Liang (1985) between the ground factor gene $P$ for pigment formation and the isozyme locus esterase- 2 . Although the $P$ locus has been removed from linkage group VI, $P$ should be retested for linkage with Cav and miv, in the event that suitable stocks carrying miv can be found.

Linkage group XI. Stavely (1984) has shown that a cluster of eight rust resistance genes is linked together in a region $\approx 9 \mathrm{cM}$ long. The evolutionary history of this chromosome region may involve repeated gene duplication and small inversions, a fascinating subject for future investigations.

Linkage groups XII and XIII. Linkages among various isozyme markers, seed proteins, and the joker gene $(J)$ have recently been reported by Gepts (1988). These protein markers include four structural genes: the small subunit of the rubisco enzyme (Rbcs), malic enzyme (Me), and the seed proteins lectin (or phytohemagglutinin) (Lec) and phaseolin $(P h s)$. The $J$ locus controls shiny $(J)$ vs. dull (j) seed coat and a major step in pigment biosynthesis (Leakey, 1988).

\section{Summary and Conclusions}

The revised linkage map of common bean has 13 linkage groups, but there are only 11 chromosome pairs. In linkage group I the genes $C a n$ and Ins were replaced by $D, U c$ was deleted, tri was added, and the complex structure of $C$ was critically reviewed, revised, and included in the map. Former linkage groups III and IV were combined into group III, and the complex structure of $I$ was included in the map. $P$ was deleted from linkage group VII (now VI). A new linkage group VII was reported with $10 \mathrm{cM}$ between $V$ and $r$, and linkage group $\mathrm{X}, p-36-$ Est2, was added to the map.

The current genetic map of common bean
(Table 1) has several markers that require additional linkage studies to determine their map orientation. Beyond this, extensive linkage studies are needed to enlarge the map and associate each linkage group with a particular chromosome. Several laboratories are working on developing molecular markers for common bean. In the near future, a large group of protein and RFLP markers will provide a backbone to the rather limited number of marker genes currently in the map. These new markers possibly will permit the assignment of linkage groups to the 11 pairs of chromosomes of common bean.

\section{Literature Cited}

Allard, R.W. 1956. Formulas and tables to facilitate the calculation of recombinational values in heredity. Hilgardia 24:235-278.

Awuma, K. and M.J. Bassett. 1988. Addition of genes for dwarf seed $(d s)$ and spindly branch $(s b)$ to the linkage map of common bean. J. Amer. Soc. Hort. Sci. 113:464-467.

Bassett, M.J. 1988. Linkage mapping of marker genes in common bean, p. 329-353. In: P. Gepts (ed.). Genetic resources of Phaseolus beans. Kluwer Academic, Dordrecht, Holland.

Bassett, M.J. 1989. List of genes-Phaseolus vulgaris L. Annu. Rpt. Bean Imp. Coop. 32:115

Bassett, M.J. and K. Awuma. 1988. Is the $P$ gene in common bean located in linkage group VII? J. Amer. Soc. Hort. Sci. 113:753-754.

Gepts, P. 1988. Provisional linkage map of common bean. Annu. Rpt. Bean Imp. Coop. 31:2025.

Kyle, M.M. and R. Provvidenti. 1987. Inheritance of resistance to potato y viruses in Phaseolus vulgaris L. I. Two independent genes for resistance to watermelon mosaic virus-2. Theor. Applied Genet. 74:595-600.

Kyle, M.M., M.H. Dickson, and R. Provvidenti. 1986. Linkage analysis of hypersensitive resistance to four viruses in Phaseolus vulgaris L. Annu. Rpt. Bean Imp. Coop. 29:80-81.

Lamprecht, H. 1936. Zur Genetik von Phaseolus vulgaris. XII. Uber die Vererbung der Blüten und Stammfarbe. Hereditas 21:129-166.

Lamprecht, H. 1940. Zur Genetik von Phaseolus vulgaris. XV. Uber die Vererbung der Merfarbigkeit Testa. Hereditas 26:65-99.

Lamprecht, H. 1947. The seven alleles of the gene $R$ of Phaseolus. Agr. Hort. Genet. 5:46-64.

Lamprecht, H. 1948a. Die Terminalverstärkung der Blütenfarbe von Phaseolus vulgaris und ihre Vererbung. Agr. Hort. Genet. 6:49-63.
Lamprecht, H. 1948b. On the effect and linkage of genes transmitted from Phaseolus coccineus to Ph. vulgaris. Agr. Hort. Genet. 6:64-81.

Lamprecht, H. 1961a. Weitere Kopplungsstudien an Phaseolus vulgaris mit einer Ubersicht über die Koppelungsgruppen. Agr. Hort. Genet. 19:319-332.

Lamprecht, H. 1961b. Die Vererbung eines Phaseolus- Typs mit drei Kotyledon sowie über die Wirkung von drei neuen Genen. Agr. Hort. Genet. 19:333-343.

Lamprecht, H. 1964. Die Vererbung eines neuen Typs von Marmorierung der Samen von Phaseolus vulgaris L. Agr. Hort. Genet. 22:256271.

Leakey, C.L.A. 1988. Genotypic and phenotypic markers in common bean, p. 245-327. In: P. Gepts (ed.). Genetic resources of Phaseolus beans. Kluwer Academic, Dordrecht, Holland.

Nagata, R.T. and M.J. Bassett. 1984. Linkage relationships of nine induced mutants in common bean. J. Amer. Soc. Hort. Sci. 109:517519.

Park, S.J. and J.C. Tu. 1986. Association between BCMV resistant $I$ gene and eye color of cv. Steuben. Annu. Rpt. Bean Imp. Coop. 29:45.

Prakken, R. 1970. Inheritance of colour in Phaseolus vulgaris L. II. Critical review. Meded. Landbouwhogeschool Wageningen 70-23:1-38.

Prakken, R. 1972a. Seedcoat colour in Phaseolus vulgaris L., attempt to a general synthesis. Annu. Rpt. Bean Imp. Coop. 15:74-79.

Prakken, R. 1972b. Inheritance of colours in Phaseolus vulgaris L. III. On genes for red seed coat colour and a general synthesis. Meded. Landbouwhogeschool Wageningen 72-29:1-82.

Prakken, R. 1974. Inheritance of colours in Phaseolus vulgaris L. IV. Recombination within the 'complex locus $C$ '. Meded. Landbouwhogeschool Wageningen 74-24:1-36.

Prakken, R. 1977. Two crosses with the "nebulosus-mottled" variety Contender (Ane Ane, from the recessive character anebulosus). Annu. Rpt. Bean Imp. Coop. 20:32-35.

Stavely, J.R. 1984. Genetics of resistance to Uromyces phaseoli in a Phaseolus vulgaris line resistant to most races of the pathogen. Phytopathology 74:339-344.

Temple, S.R. and F.J. Morales. 1986. Linkage of dominant hypersensitive resistance to bean common mosaic virus to seed color in Phaseolus vulgaris L. Euphytica 35:331-333.

Weeden, N.F. and C.Y. Liang. 1985. Detection of a linkage between white flower color and EST-2 in common bean. Annu. Rpt. Bean Imp. Coop. 28:87-88 